\title{
PENURUNAN TEKANAN DARAH PENDERITA HIPERTENSI SETELAH DIBERIKAN TERAPI AKUPRESUR
}

\author{
Aminuddin $^{1 凶}$, Yulianus Sudarman ${ }^{2}$, Moh Syakib ${ }^{2}$ \\ ${ }^{1}$ Jurusan Keperawatan Prodi Ners Poltekkes Kemenkes Palu \\ ${ }^{2}$ Jurusan Keperawatan Prodi D IV Keperawatan Poltekkes Kemenkes Palu
}

\section{ARTICLE INFO \\ Article history \\ Submitted : 2019-03-04 \\ Revised : 2020-07-03 \\ Accepted : 2020-07-24}

Keywords:
Acupressure Therapy
Blood Pressure
Hypertension

\section{Kata Kunci:}

Terapi Akupresur

Tekanan Darah

Hipertensi

\begin{abstract}
Hypertension or high blood pressure is one of the silent killers. The results of a preliminary study found that 7 out of 11 who suffer from hypertension have done massage on the head, neck, shoulders, and back, but patients said doing massage just to reduce headaches without knowing which point should be pressed for hypertension. The purpose of this study was to determine the effect of acupressure therapy on reducing blood pressure in hypertensive patients in the working area of Mamboro Health Center. This study was an analytic study using pre-experiment with one group pre and post-test design. The number of samples in this study was 7 respondents who were calculated using the formula Lemeshow. The sampling technique was purposive sampling. Data analysis was analyzed using univariate and bivariate with paired t-test. The results showed the distribution of blood pressure frequency of respondents after acupressure therapy. There were 5 people $(71.42 \%)$ decreased and 2 people $(28.58 \%)$ remained. This study concludes that there is an effect of acupressure therapy on the reduction of blood pressure in hypertensive patients. Suggestions for Mamboro health centers, the results of this study can be used as input in setting policies to implement complementary therapy for hypertensive patients.
\end{abstract}

Hipertensi atau penyakit tekanan darah tinggi merupakan salah satu pembunuh diamdiam (silent killer) di antara pembunuh lainnya. Hasil studi pendahuluan ditemukan ada 7 dari 11 yang menderita hipertensi sudah melakukan pijatan pada daerah kepala, leher, bahu dan punggung, namun penderita mengatakan melakukan pijat hanya untuk mengurangi sakit kepala tanpa mengetahui titik mana yang harus ditekan untuk hipertensi. Tujuan pada penelitian ini adalah diketahuinya pengaruh pemberian terapi akupresur terhadap penurunan tekanan darah pada pasien hipertensi di wilayah kerja Puskesmas Mamboro. Desain penelitian ini merupakan penelitian analitik dengan menggunakan pra eksperimen dengan one grouppre dan post testdesign. Jumlah sampel dalam penelitian ini yaitu 7 responden yang dihitung dengan menggunakan rumus lemeshow. Teknik pengambilan sampel secara purposive sampling. Analisa data adalah analisisunivariat dan analisis bivariat dengan uji statistik paired t-test. Hasil penelitian menunjukkan distribusi frekuensi tekanan darah responden setelah terapi akupresur dari 7 responden terdapat 5 orang $(71,42 \%)$ terjadi penurunan dan 2 orang $(28,58 \%)$ tetap. Kesimpulan penelitian ini bahwa ada pengaruh pemberian terapi akupresur terhadap penurunan tekanan darah pada pasien hipertensi. Saran bagi puskesmas Mamboro, hasil penelitian ini dapat dijadikan sebagai bahan masukan dalam menetapkan kebijakan dalam upaya menerapkan terapi komplementer bagi pasien hipertensi.

\footnotetext{
Corresponding Author:
}

Aminuddin

Jurusan Keperawatan Prodi Ners Poltekkes Kemenkes Palu

Telp. 085241438132

Email: aminuddinpalu1971@gmail.com

\section{PENDAHULUAN}

Tekanan sistol (tekanan darah saat jantung menguncup) $>140 \mathrm{mmHg}$ dan tekanan diastol (tekanan darah saat jantung mengembang) >90 mmhg yang didapatkan lewat pengukuran dua kali secara berurutan menegakkan diagnosis hipertensi (Widodo, 2014).

Terlepas dari kemajuan dalam pencegahan dan pengobatan hipertensi, ada persentase yang tinggi dari orang-orang dengan tekanan darah tinggi atau tidak terkontrol. Diperlukan strategi baru yang 
berpusat pada pasien untuk mendukung orang yang mengelola kondisi mereka (Lopez, 2018). Tekanan darah sentral telah mendapatkan perhatian dalam pengelolaan hipertensi (Cheng et al., 2020).

Akupresur lebih banyak dimaksudkan untuk penyegaran tubuh. Cara pemijatan metode akupresur berbeda dengan cara pemijatan refleksologi. Metode pemijatan akupresur dilakukan dengan menekan atau menggetarkan (vibration), selama $15-20$ detik untuk tiap tempat atau titik (Tarumetor, 2007) (Tarumetor T J H, 2007). Data yang diperoleh dari Puskesmas Mamboro pada tahun 2015 penderita hipertensi berjumlah 227 kasus, tahun 2016 penderita hipertensi berjumlah 490 kasus. Penderita hipertensi 2017 berjumlah 568 kasus (Puskesmas Mamboro, 2017). Tujuan penelitian diketahuinya pengaruh pemberian terapi akupresur terhadap tekanan darah pada pasien hipertensi di wilayah kerja Puskesmas Mamboro.

\section{METODE PENELITIAN}

\section{Jenis Penelitian}

Penelitian ini menggunakan metode penelitian analitik dengan menggunakan desain penelitian pra eksperimen dengan one group pre dan post test design.

\section{Lokasi dan Waktu Penelitian}

Penelitian ini berlokasi di wilayah kerja Puskesmas Mamboro. Penelitian dilaksanakan pada tanggal 30 Juni sampai dengan 21 Juli 2018

\section{Populasi dan Sampel}

Populasi dalam penelitian adalah seluruh masyarakat yang menderita hipertensi di wilayah kerja Puskesmas Mamboro. Sampel menggunakan rumus Lemeshow dengan jumlah 7 responden.

Kriteria inklusi yaitu tekanan darah Sistol $\geq 140 \mathrm{mmHg}$ dan diastol $\geq 90 \mathrm{mmHg}$ yang didapatkan dalam 2 kali pengukuran dan pasien dalam keadaan santai, tidak mengonsumsi obat anti hipertensi dalam waktu kurang dari 48 jam. Kriteria eksklusi yaitu tidak mengalami kulit yang terluka, tulang retak dan kulit terbakar.

\section{Teknik Pengambilan Data}

Pengambilan data primer didapatkan pada responden yang mengalami hipertensi dengan menggunakan wawancara langsung dan melakukan pengukuran tekanan darah kemudian dilanjutkan dengan terapi akupresur, 10 menit kemudian setelah diberikan terapi akupresur kembali dilakukan pengukuran tekanan darah. Terapi akupresur diberikan sebanyak 3 kali dalam sehari pada responden selama 2 hari berturut-turut.

\section{Analisis Data}

Analisis Univariat pada penelitian ini yaitu untuk melihat nilai mean (rata-rata), standar deviasi, minimum dan maksimum sebelum dan sesudah tindakan terapi akupresur pada pasien hipertensi Analisis bivariat menguji signifikansi hasil $t$ hitung dibandingkan dengan t tabel.

\section{HASIL PENELITIAN}

Analisa Univariat

Hasil penelitian ini menunjukkan bahwa dari 7 responden yang berusia $46-55$ tahun lebih banyak $(57,14 \%)$ dan dari 7 responden lebih banyak laki-laki $(57,14 \%)$.

Tabel 1. Karakteristik Responden Berdasarkan Umur dan Jenis Kelamin

\begin{tabular}{lcc}
\hline \multicolumn{1}{c}{ Variabel } & Frekuensi (n) & Presentase (\%) \\
\hline Usia (Tahun) & & \\
$40-45$ & 1 & 14,28 \\
$46-55$ & 4 & 57,14 \\
$56-59$ & 2 & 28,58 \\
Total & 7 & 100 \\
Jenis Kelamin & & \\
Laki-laki & 3 & 42,86 \\
Perempuan & 4 & 57,14 \\
Total & 7 & 100 \\
\hline
\end{tabular}




\section{Variabel Penelitian}

Tabel 2. menunjukkan dari 7 responden post test terjadi penurunan tekanan darah sistolik sebanyak 7 orang $(100 \%)$ dan penurunan tekanan darah diastolik sebanyak 5 orang $(71,42 \%)$, tekanan darah diastolik tetap sebanyak 2 rang $(28,58)$.

Tabel 3. menunjukkan bahwa tekanan darah sistolik sebelum diberikan terapi akupresur yaitu rata-rata $144,76 \mathrm{mmHg}$ tekanan darah diastolik sebelum diberikan terapi akupresur yaitu rata-rata 90,95 $\mathrm{mmHg}$. Tekanan darah sistolik setelah diberikan terapi akupresur yaitu rata-rata 140,24 $\mathrm{mmHg}$ dan tekanan darah diastolik setelah diberikan terapi akupresur yaitu rata-rata $86,67 \mathrm{mmHg}$.

Tabel 2. Distribusi Frekuensi Tekanan Darah Responden Setelah Terapi Akupresur di Wilayah Kerja Puskesmas Mamboro

\begin{tabular}{ccccc}
\hline \multirow{2}{*}{ Tekanan Darah } & \multicolumn{2}{c}{ Sistolik } & \multicolumn{2}{c}{ Diastolik } \\
\cline { 2 - 5 } & $\mathbf{n}$ & $\mathbf{\%}$ & $\mathbf{n}$ & $\mathbf{\%}$ \\
\hline Naik & 0 & 0 & 0 & 0 \\
Tetap & 0 & 0 & 2 & 28,58 \\
Turun & 7 & 100 & 5 & 71,42 \\
Total & 7 & 100 & 7 & 100 \\
\hline
\end{tabular}

Tabel 3. Rata-Rata Tekanan Darah Responden Sebelum dan Setelah diberikan Terapi Akupresur di Wilayah Kerja Puskesmas Mamboro

\begin{tabular}{cccccccccc}
\hline \multirow{2}{*}{ Tekanan darah Sebelum Terapi } & \multicolumn{3}{c}{ Setelah Terapi } \\
\cline { 2 - 10 } & Mean & SD & Min & Max & Mean & SD & Min & Max \\
\hline Sistolik & 144.76 & 6.713 & 130 & 90 & 140.24 & 6.435 & 130 & 150 \\
Diastolik & 90.95 & 2.971 & 160 & 100 & 86.67 & 4.771 & 80 & 90 \\
\hline
\end{tabular}

\section{Analisis Bivariat}

Hasil uji kenormalan data pada tekanan darah sistolik sebelum tindakan 0 tekanan darah diastolik sebelum tindakan 0,047 dan tekanan darah sistolik setelah tindakan 0.047 , tekanan darah diastolik setelah tindakan 1,54 hal ini menyatakan nilai $<2$, berarti data terdistribusi normal, karena data terdistribusi normal maka digunakan uji paired t-test tingkat kepercayaan $95 \%$ p value $(\geq \alpha 0,05)$.

Tabel 4. Pengaruh Pemberian Terapi Akupresur Terhadap Tekanan Darah Pada Pasien Hipertensi Di Wilayah Kerja Puskesmas Mamboro

\begin{tabular}{ccc}
\hline Tekanan darah & Beda Mean & $\boldsymbol{p}$ value \\
\hline Sistolik post test & 15,714 & 0,000 \\
Diastolik post test & 11,429 & 0,015 \\
\hline
\end{tabular}

Tabel di atas menunjukkan bahwa hasil analisis uji statistik paired t-test tekanan darah sistolik dan diastolik sesudah terapi akupresur didapatkan $p$ value $=0,000(\alpha<0,05)$, beda mean $=15,714$ untuk sistolik dan $p$ value $=$ $0,015(\alpha<0,05)$, beda mean $=11,429$ untuk diastolik. Sesuai dengan hipotesis penelitian maka Ho ditolak dan Ha diterima yang artinya ada pengaruh pemberian terapi akupresur terhadap tekanan darah pada pasien hipertensi.

\section{PEMBAHASAN}

Hasil penelitian menunjukkan dari 7 responden post test terjadi penurunan tekanan darah sistolik sebanyak 7 orang $(100 \%)$ dan penurunan tekanan darah diastolik sebanyak 5 
orang $(71,42 \%)$, tekanan darah diastolik tetap sebanyak 2 rang $(28,58 \%)$.

Hasil tersebut peneliti berasumsi bahwa ada 2 responden yang tekanan darah diastoliknya tetap tetapi tekanan darah sistoliknya turun. Karena 2 responden tersebut berjenis kelamin perempuan, berusia 58 dan 59 tahun bahwa usia tersebut mendekati usia lansia dimana terjadinya massa menopause bagi perempuan.

Asumsi peneliti di atas didukung teori yang dikemukakan oleh Dalmartha (2008) yang menyatakan bahwa peningkatan risiko hipertensi pada perempuan terjadi pada massa menopause yaitu sekitar 45 tahun ke atas (Dalimartha, 2008). Menurut Greenspan \& Baxter, (1998) dalam Finasari (2014) juga menyatakan hal ini akan menyebabkan fungsi ovarium normal berangsur-angsur menghilang dan kadar estrogen turun setelah pasca menopause sehingga terjadi peningkatan dari kadar kolesterol dan low density lipoprotein (LDL), sementara reseptor untuk LDL menjadi berkurang dan dapat menyebabkan tekanan darah meningkat (Finasari, 2014).

Asumsi peneliti di atas didukung juga teori yang dikemukakan oleh (Agnesia,2012) dalam (Widodo, 2014) bahwa faktor usia sangat berpengaruh terhadap hipertensi karena dengan bertambahnya usia maka risiko hipertensi menjadi lebih tinggi. Insiden hipertensi yang makin meningkat dengan bertambahnya usia disebabkan oleh perubahan alamiah dalam tubuh yang mempengaruhi jantung, pembuluh darah dan hormon (Widodo, 2014).

Brunner dan Suddarth (2015) mengemukakan bahwa perubahan struktural dan fungsional pada sistem pembuluh perifer bertanggung jawab pada perubahan tekanan darah yang terjadi pada usia lanjut (Brunner and Suddarth, 2015). Perubahan tersebut meliputi ateriosklerosis, hilangnya elastisitas jaringan ikat dan penurunan dalam relaksasi otot polos pembuluh darah, yang pada gilirannya menurunkan kemampuan distensi dan daya regang pembuluh darah. Akibatnya aorta dan arteri besar berkurang kemampuannya dalam mengakomodasi volume darah yang dipompa oleh jantung (volume sekuncup) dan mengakibatkan penurunan curah jantung dan peningkatan tahanan perifer.

Widodo (2014) dengan judul penelitian pengaruh terapi akupresur pada pasien hipertensi di klinik synergi mind healt
Surakarta dengan jumlah responden sebanyak 10 orang hasil penelitian tersebut menunjukkan bahwa ada 2 orang yang berusia 56 dan 57 tahun tekanan darah diastoliknya tetap setelah diberikan terapi akupresur (Widodo, 2014).

Asumsi peneliti berdasarkan hasil tersebut adalah ketika terapi akupresur diberikan menyebabkan penurunan stres pada responden, peredaran darah menjadi lancar dan responden menjadi rileks sehingga tekanan darah berangsur-angsur menjadi turun. Asumsi peneliti tersebut didukung oleh teori Potter \& Perry (2010). Bahwa akupresur dapat menstimulasi saraf-saraf di superficial kulit yang kemudian diteruskan ke otak di bagian hipotalamus. Sistem saraf desenden melepaskan opiat endogen seperti hormon endorphin (Potter, 2010). Pengeluaran hormon endorphin mengakibatkan meningkatnya kadar hormon endorphin di dalam tubuh yang akan meningkatkan produksi kerja hormon dopamin. Peningkatan hormon dopamin mengakibatkan terjadinya peningkatan aktivitas sistem saraf parasimpatis. Sistem saraf parasimpatis berfungsi mengontrol aktivitas yang berlangsung dan bekerja pada saat tubuh rileks, sehingga penderita hipertensi mempersepsikan sentuhan sebagai stimulus respon relaksasi dan menyebabkan penurunan tekanan darah.

Penelitian ini juga sejalan dengan penelitian yang dilakukan oleh Widodo (2014) yang berjudul pengaruh terapi akupresur pada pasien hipertensi di klinik synergi mind healt Surakarta. Hasil penelitian tersebut menunjukkan bahwa ada pengaruh terapi akupresur terhadap penurunan tekanan darah pasien hipertensi (Widodo, 2014).

Penelitian lain yang dilakukan oleh Nopri dkk. (2015) dengan judul efektivitas kombinasi terapi slow stroke back massage dan akupresur terhadap penurunan tekanan darah pada penderita hipertensi (Nopri, Ari and Erwin, 2015). Hasil penelitian tersebut menunjukkan bahwa terdapat pengaruh yang signifikan antara pemberian terapi slow stroke back massage dan akupresur terhadap penurunan tekanan darah pada penderita hipertensi.

\section{KESIMPULAN DAN SARAN}

Rata-rata tekanan darah sebelum dilakukan terapi akupresur yaitu 144,76/90,95 $\mathrm{mmHg}$, rata-rata tekanan darah setelah dilakukan terapi akupresur yaitu 140,24/86,67 mmHg. Ada 
pengaruh pemberian terapi akupresur terhadap penurunan tekanan darah pada pasien hipertensi di wilayah kerja puskesmas Mamboro. Hasil penelitian ini dapat dijadikan sebagai bahan masukan dalam menetapkan kebijakan dalam upaya menerapkan terapi komplementer bagi pasien hipertensi.

\section{DAFTAR PUSTAKA}

Brunner and Suddarth (2015) Buku Ajar Keperawatan Medikal Bedah. 12th edn. EGC.Jakarta.

Cheng, H. M. et al. (2020) 'Central blood pressure for the management of hypertension: Is it a practical clinical tool in current practice?', Journal of Clinical Hypertension, 22(3), pp. 391-406. doi: $10.1111 / \mathrm{jch} .13758$.

Dalimartha (2008) Hipertensi your self. Jakarta: EGC.

Finasari (2014) Perbedaan Terapi Musik Klasik dan Musik yang Disukai Terhadap tekanan Darah pada Pasien Hipertensi di RSUD Dr. H. Soewondo Kendal.
Lopez, A. L. S. (2018) 'Effectiveness of the Mindfulness-Based Stress Reduction Program on Blood Pressure: A Systematic Review of Literature', Worldviews Evid Based Nurs, 15(5), pp. 344-352. doi: 10.1111/wvn.12319.

Nopri, A., Ari, P. and Erwin (2015) 'Efektifitas Kombinasi Terapi Slow Stroke Back massage dan Akupresur Terhadap Penurunan Tekanan Darah pada Penderita Hipertensi', Journal Keperawatan, 2(2), pp. 1999 - 1305.

Potter, P. A. (2010) Fundamental keperawatan. Elsevier.

Puskesmas Mamboro (2017) Laporan Tahunan Puskesmas Mamboro. Palu: Laporan Tahunan Puskesmas Mamboro.

Tarumetor T J H (2007) Refleksologi: Penyembuhan Penyakit dengan Pijat Pembuluh Darah dan Pusat Saraf. Jakarta: Rineka Cipta.

Widodo, D. S. D. (2014) Pengaruh Terapi Akupresur pada Pasien Hipertensi di Klinik Synergi Mind Health Surakarta. 